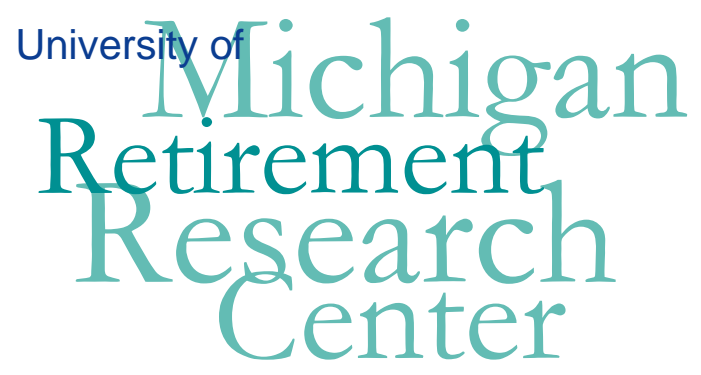

Working Paper

WP 2008-194

Labor Supply Effects of the Interaction between the Social Security Disability and Retirement Programs at Full Retirement Age

Nicole Maestas and $\mathrm{Na}$ Yin

\begin{tabular}{|l|l|l|l|l}
\hline $\mathrm{M}$ & $\mathrm{R}$ & Project \#: UM08-13 \\
\hline $\mathrm{R}$ & $\mathrm{C}$ &
\end{tabular} 


\title{
Labor Supply Effects of the Interaction between the Social Security Disability and Retirement Programs at Full Retirement Age
}

\author{
Nicole Maestas \\ RAND \\ $\mathrm{Na}$ Yin \\ Baruch College-CUNY \\ September 2008 \\ Michigan Retirement Research Center \\ University of Michigan \\ P.O. Box 1248 \\ Ann Arbor, MI 48104 \\ http://www.mrrc.isr.umich.edu/ \\ (734) 615-0422
}

\section{Acknowledgements}

This work was supported by a grant from the Social Security Administration through the Michigan Retirement Research Center (Grant \# 10-P-98362-5-04). The findings and conclusions expressed are solely those of the author and do not represent the views of the Social Security Administration, any agency of the Federal government, or the Michigan Retirement Research Center.

\section{Regents of the University of Michigan}

Julia Donovan Darrow, Ann Arbor; Laurence B. Deitch, Bingham Farms; Olivia P. Maynard, Goodrich; Rebecca McGowan, Ann Arbor; Andrea Fischer Newman, Ann Arbor; Andrew C. Richner, Grosse Pointe Park; S. Martin Taylor, Gross Pointe Farms; Katherine E. White, Ann Arbor; Mary Sue Coleman, ex officio 


\title{
Labor Supply Effects of the Interaction between the Social Security Disability and Retirement Programs at Full Retirement Age
}

\author{
Nicole Maestas and Na Yin
}

\begin{abstract}
The Social Security Disability Insurance (DI) program imposes strong work restrictions on beneficiaries; however, the causal effect of the work disincentives on labor supply has been difficult to estimate. We take a new look at this question by exploiting the fact that DI benefits are payable only until full retirement age (FRA), at which point they are converted to retired worker benefits, and the program's implicit high marginal tax rate on earnings is abruptly relaxed. Using a quasi-experimental research design, we examine whether the DI work disincentives are binding by comparing changes in labor force participation rates before and after the FRA for DI beneficiaries and non-beneficiaries. We find a relative increase in labor force participation at FRA for DI beneficiaries of 10.4 percentage points, and argue that this is likely a lower bound estimate on the labor supply disincentive effects of the DI program.
\end{abstract}

\section{Authors’ Acknowledgements}

We gratefully acknowledge financial support from the Michigan Retirement Research Center under grant \#UM08-13. We thank Xiaoyan Li for expert assistance with the HRS data files. 


\section{Introduction}

Extensive research effort has been devoted to understanding the labor supply effects of social insurance programs, especially in light of the historical decline in male labor force participation. In particular, the Social Security Disability Insurance (DI) program has attracted the attention of policymakers and researchers alike, as it has grown dramatically since inception, and features a particularly strong work disincentive: an implicit 100,000 percent marginal tax rate on earnings above a threshold deemed to represent "substantial gainful activity" (SGA) (\$940/month in 2008). Indeed, the decline in male labor force participation has been attributed at least in part to DI (Bound and Waidmann 1992; 2002; Autor and Duggan, 2003). Over the last two decades, the DI caseload has shifted from one characterized by individuals with circulatory, neoplasms and infectious diseases to one dominated by individuals with mental and musculoskeletal impairment. ${ }^{1}$ This compositional shift has renewed interest in the work disincentives associated with the DI program and has increased the possibility that some form of work might be possible for some DI recipients.

Nevertheless, the causal effect of DI on labor supply is difficult to estimate since all U.S. workers face the same benefit schedule. As a result, observed variation in benefits is due mainly to past earnings, which may be correlated with unobserved health status or tastes for work. Lacking either exogenous variation in program generosity or a means of controlling for unobserved heterogeneity, only a handful of studies have succeeded in obtaining credible estimates of the effect of DI on labor supply (e.g., Bound 1989, Bound and Waidmann 1992; Gruber and Kubik 1997; Gruber 2000; Autor and Duggan 2003; Chen and van der Klaauw

\footnotetext{
${ }^{1}$ See Trends in the Social Security and Supplemental Security Income Disability Programs (released by the Social Security Administration in 2006), pp. 44.
} 
2008), and even these have come to different conclusions about the magnitude of the work disincentive effects of DI.

We take a new look at this question by exploiting a little-studied interaction between DI and the Social Security retirement program, and a recent policy change that changed the nature of the program interaction. Specifically, DI benefits are payable to eligible individuals until they reach their full retirement age, at which point DI benefits automatically convert to retired worker benefits under the Old-Age and Survivors Insurance (OASI) program. While the terms governing the benefit amount change, the benefit amount itself remains unchanged. Thus, since they are no longer subject to the strict DI work rules, the implicit tax on earnings is abruptly relaxed at exactly full retirement age. Moreover, the extent to which the implicit tax is relaxed has varied over time owing to the year 2000 elimination of the Social Security earnings test after the full retirement age. Prior to 2000, DI participants attaining full retirement age faced a reduction in the implicit marginal tax rate from approximately 100,000 percent to 50 percent (on an even higher exempt amount), the implicit tax rate imposed by the OASI earnings test at full retirement age. In 2000, the earnings test at the full retirement age was eliminated, and thus DI participants attaining full retirement age in 2000 or later experienced complete elimination of the implicit tax at full retirement age. If the work disincentive is binding on DI participants, then we would expect to observe an increase in labor supply at full retirement age.

We use a quasi-experimental research design to estimate the labor supply disincentive effect of DI. Specifically, using the Health and Retirement Study (1992-2006) we contrast the within-individual change in labor supply at full retirement age for DI beneficiaries versus nonbeneficiaries. Besides using within-individual changes to difference out unobserved heterogeneity, we make use of the longitudinal aspect of the HRS to control for 
contemporaneous changes in other factors such as non-labor income, wealth, health, and health insurance coverage. The natural experiment we examine offers direct insight into the potential effects of a current policy proposal termed the " $\$ 1$ for $\$ 2$ benefit offset," which would reduce the current 100,000 percent implicit marginal tax rate to 50 percent. Benitez-Silva, Buchinsky, and Rust (2006) use a structural model to simulate the effect of implementing such a policy and predict large increases in labor force participation among DI beneficiaries.

The literature to date has sought to establish an upper bound on the work capacity of DI participants. Bound (1989) studied the subsequent labor supply of rejected DI applicants (who should have been in marginally better health on average than accepted applicants) and concluded that labor force participation among 55-64 year-old men in the absence of the program would have been no greater than 34 percent in the 1970s. Chen and van der Klauuw (2008) use Bound's approach as well as age-based discontinuities in the eligibility determination formula to estimate the program's impact on labor supply (of both men and women) and conclude that labor force participation in the 1990s would have been at most 20 percentage points higher in the absence of the program.

Our approach complements these findings in that it identifies a lower bound on the potential work capacity of DI beneficiaries. By examining changes in labor force participation as the oldest DI beneficiaries age out of the program, we examine a subpopulation of DI beneficiaries who are perhaps least likely to exhibit a labor supply response to changes in work incentives. $^{2}$ Indeed, the dominant trend in labor supply at full retirement age is downward. Any increase in labor force participation among this group serves as strong evidence of the existence of residual work capacity among DI recipients. Its magnitude is an indicator of the minimum

\footnotetext{
${ }^{2}$ Individuals between age 60 and FRA represent about one-fifth to one-quarter of the DI caseload during the period we study 1992-2006 (Social Security Administration, 2008).
} 
work capacity of DI beneficiaries because the disabled elderly are likely to be in worse health than the younger disabled and employment opportunities for even the non-disabled elderly are limited (see Maestas and Li ( 2006) for recent evidence).

Our difference-in-difference (DD) estimates imply a modest 10.4 percentage point rise in labor force participation at full retirement age among former DI participants relative to non-DI participants. There is some evidence that the labor supply response was stronger after elimination of the Social Security earnings test, suggesting a dose-response relationship between the size of the work disincentive and labor supply. Combining our estimates with Chen and van der Klauuw's (2008) upper bound estimate of 20 percentage points would suggest that the DI program causes a modest 10 -20 percentage point reduction in labor force participation among beneficiaries.

\section{Institutional Background}

\subsection{The DI Program}

The U.S. Social Security Disability Insurance program, instituted in 1956, was designed to provide income replacement to workers who were deemed permanently, and totally disabled. Individuals are entitled to benefits if they have worked in covered employment for five of the past ten years. Unlike disability systems in many other countries, it is not a temporary disability system, nor does it prorate benefits for partial disabilities. ${ }^{3}$ Consequently, the system operates from an underlying presumption that DI recipients are unable to work. Applicants must demonstrate that they did not work during the five months prior to initial application, and once they begin receiving benefits they are prohibited from earning more than the threshold defining substantial gainful activity (SGA) (\$940 per month in 2008). Since 1960, DI recipients have

\footnotetext{
${ }^{3}$ In many OECD countries, the public contributory disability system awards prorated disability benefits to those deemed partially disabled. See Yin (2008) for a detailed comparison of full and partial disability benefit systems.
} 
been permitted to "test" their ability to work during a Trial Work Period. During the Trial Work Period, which begins in the first month of program participation and extends for five years, benefits are maintained until the beneficiary accumulates nine months of work above the SGA threshold. ${ }^{4}$ In the tenth month, for the first $\$ 1$ of earnings above this threshold, benefits are terminated. For the average DI beneficiary receiving a monthly benefit of $\$ 1053$ in 2007, this amounts to a staggering 100,000 percent implicit marginal tax rate on earnings. ${ }^{5}$ Since 1980 , those who have had their benefits terminated for substantial gainful activity can reinstate benefits (without a new application, waiting period, or disability determination) during a three-year period (called the Extended Period of Eligibility) after the Trial Work Period in the event they stop working and are still disabled.

Figure 1 illustrates the implied DI budget constraint (ABCDE) for an individual after nine accumulated work months during the Trial Work Period, or in the first month of work after the Trial Work Period has ended. The segment AB equals the DI benefit received by a nonworker who has applied and been accepted by the DI program. ${ }^{6}$ As long as earnings are below the SGA threshold, a DI recipient may keep her disability benefits; ${ }^{7}$ this is illustrated by the segment BC, the slope of which in absolute value equals the hourly wage rate. However, once hours of work cause earnings to exceed the SGA limit, benefits are terminated, as reflected by the notch $\mathrm{CD}$, which equals the length of $\mathrm{AB}$. This notch reflects the high implicit marginal tax rate on earnings. The indifference curves superimposed on the budget constraint illustrate how an individual who in the absence of the program might work hours $>H_{S G A}$, would in the presence

\footnotetext{
${ }^{4}$ Until 1992, the nine months had to be consecutive.

${ }^{5}$ This contrasts with implicit tax rates in other social programs, like TANF which range from 6 percent to 30 percent (Coe et al., 1998).

${ }^{6}$ We do not consider the probability of being eligible for DI benefits because our focus is on "exit" from the program. The budget constraint with acceptance uncertainty has been illustrated by Halpern and Hausman (1986).

${ }^{7}$ Since 2001, the SGA amount has been adjusted annually in line with the national average wage index.
} 
of the program attain a higher level of utility by reducing labor supply to hours $=H_{S G A}$. It is not obvious, however, how many disabled individuals would be able to work hours $>H_{S G A}$ in the absence of the program.

The emphasis of recent policy reforms has been on offering employment services to DI participants. The Ticket to Work Program, established in 1999 under the Ticket to Work Incentive and Work Incentives Improvement Act (TWWIIA) makes available a voucher (or “ticket”) that can be used to obtain vocational rehabilitation and employment services within an approved network of public and private providers. ${ }^{8}$ The program was phased in between 2001 and 2004. ${ }^{9}$ The TWWIIA also extended Medicare coverage to beneficiaries who return to work by offering them continuation of premium-free Medicare Part A for 93 months after the end of the Trial Work Period and the option to purchase Medicare Part B.

\subsection{Interaction with OASI at Full Retirement Age}

Once a DI beneficiary reaches full retirement age, his benefits automatically convert to Social Security retirement benefits. The benefit amount itself does not change; but the terms governing receipt of the benefit do change - the DI work rules are abruptly relaxed, and the rules governing the Social Security earnings test become binding. Prior to 2000, the earnings test amounted to an implicit marginal tax of 50 percent on earnings above an exempt threshold ${ }^{10}$; after 2000, the earnings test was eliminated for OASI beneficiaries above their full retirement age (but retained for those between early retirement age and full retirement age). In terms of the

\footnotetext{
${ }^{8}$ According to a report by Mathematica (2007), the participation rate in the Ticket to Work program in the early implementing states has been much lower than anticipated (1.4 percent). This is more likely a reflection of documented implementation difficulties than an indication of very low residual work capacity among DI beneficiaries.

${ }^{9}$ New regulations in 2008 aim to expand ticket eligibility, attract more service providers, and expand the range of rehabilitation and employment services offered.

${ }^{10}$ The exempt threshold has varied over time. See http://www.ssa.gov/OACT/COLA/rtea.html.
} 
budget constraint depicted in Figure 1, the transition at FRA amounts to an abrupt upward shift in the line segment DE such that it connects directly with point C. Prior to 2000, the slope of the line segment flattened at the hours threshold associated with the OASI earnings test exempt amount (which was generally a bit higher than the SGA threshold); after 2000 there was no slope change at all and segment DE became an extension of BC.

\section{Research Design}

\subsection{Data}

We use the first eight waves of the longitudinal Health and Retirement Study, which cover the period 1992-2006 in a sequence of biennial interviews. We restrict our analysis sample to HRS respondents who attain their Social Security full retirement age (FRA) at any point after their baseline interview and before their last interview. ${ }^{11}$ Ninety percent of the sample belongs to the original HRS cohort (b. 1931-1941) and 10 percent come from the CODA cohort (b. 19271930). Seventy-three percent of the sample has an FRA of 65, 10 percent has an FRA of 65 and 2 months, 9 percent has an FRA of 65 and 4 months, and 8 percent have an FRA of 65 and 6 months. The sample consists of 57,928 person-wave observations contributed by 7,241 unique individuals. Of this group, 9.3 percent (670 respondents) report participation in the DI program in the wave prior to attaining their FRA, that is, at ages $63-64 .{ }^{12}$ Over the course of the study period, these 670 individuals contribute 5,360 person-wave observations.

In the HRS, DI participation is measured in two ways, by self-report and matched SSA administrative records. The administrative match rate is quite low (just 47.8 percent of our sample has a matched record) and therefore we make use of the self-reported data. A limitation of the self-reported variable is that the question wording changed over time; the survey question

\footnotetext{
${ }^{11}$ Respondents who attrit from the HRS after attaining their FRA are retained in the sample.

${ }^{12}$ Because the HRS is a biennial survey, most individuals who were 63-64 in one wave attained full retirement age by the next wave.
} 
grouped DI and SSI together in waves 1-4, but asked about the programs separately in waves 58. We address this limitation by combining DI and SSI in the later waves so that we have a consistent measure of combined DI-SSI participation over time. Since we are primarily interested in DI participation, this induces measurement error in our dependent variable; however, the problem is slightly mitigated by the overlap in the DI and SSI populations (14-16 percent of DI beneficiaries also participate in SSI (Social Security Administration, 2008)) and the fact that the SSI program has similar work disincentives. Comparing self-reported participation with the administrative data among the subgroup of matched respondents in our sample suggests that the inclusion of SSI adds about 1-2 percentage points to our measured DI participation rate.

Table 1 presents pre-period descriptive statistics for the sample of individuals on DI at ages 63-64 and those not on DI at ages 63-64. All statistics are measured as of the wave prior to attaining full retirement age. By construction, the mean ages are nearly identical (63.5 v. 63.6), and the full retirement age of the median individual in both groups is 65. As expected, the DI sample is worse off in terms of socioeconomic status and health. DI beneficiaries are disproportionately black, have fewer years of schooling, are less likely to be married, have less than half the net worth ${ }^{13}$ of non-DI participants, and are less healthy on all 13 measures of health status. They have higher SSA income (i.e., income from DI, SSI, and OA), reflecting the facts that DI participants receive DI benefits based on their full primary insurance amount (PIA) while many of those not on DI have not yet claimed SSA retirement benefits, and those who have claimed have received actuarial reductions for early claiming. They are also more likely to have

\footnotetext{
${ }^{13}$ Net worth is the sum of assets (primary residence, other real estate, vehicles, businesses, IRAs, stocks, bonds, checking accounts, CDs, and other assets) less liabilities (mortgages, other home loans, and other debt).
} 
health insurance coverage, due to the fact that Medicare becomes available to DI participants after a waiting period of 24 months.

\subsection{Quasi-Experimental Design}

In our quasi-experimental research design we take a DI participant attaining full retirement age to be an "instrument” for the abrupt relaxation of the DI work disincentives. We use a difference-in-differences (DD) estimator, where the first difference is between labor force participation before and after full retirement age and the second difference is between DI participants (the "treatment” group) and non-DI participants (the comparison group). ${ }^{14}$ Because we have panel data, we take the within-individual change in labor force participation before and after attainment of full retirement age. This is desirable as it guarantees comparability of the groups in the pre- and post-periods, controlling for any compositional changes due to attrition or sampling variation.

The identifying assumption in DD models is that other time-varying processes would have similarly impacted the treatment and comparison groups. The pre-period differences between the groups in Table 1 suggest a potential vulnerability on this front (Meyer, 1995). We address this by testing for differential changes in a number of potential confounders, including health status, health insurance coverage, and non-labor income. We then present in addition to unadjusted DD estimates, estimates that account for within-individual changes in these and other relevant variables.

\section{Labor Supply Response of DI Recipients at Full Retirement Age}

\subsection{Descriptive Evidence}

\footnotetext{
${ }^{14}$ An alternative approach is to use a regression-discontinuity estimator comparing the labor supply behavior of disabled individuals just before and just after attainment of their full retirement age; however, because such estimators require a large number of observations in a "small enough" window on either side of the full retirement age, we do not have enough observations in the HRS to make such a design feasible.
} 
Figure 2 shows labor force participation by age for DI recipients on the left axis and selfreported DI program participation by age on the right axis. Self-reported DI participation drops from just over 9 percent prior to age 65 (the full retirement age for most of the sample), to about 7 percent at ages 65-66 and just under 5 percent at 67-68. In theory, DI participation rates should drop to zero at ages 65-66, since DI beneficiaries are automatically transferred to the SSA retirement program at their full retirement age; however, the gradual decline in self-reported participation shown in the figure likely reflects two factors: first, as noted above our measure of DI participation includes SSI participation, and some individuals may continue to be eligible for SSI once they reach FRA. A second possibility is that some respondents do not immediately realize that they are no longer on DI. If so, they may be unaware of the change in program rules, which should bias down the estimated effect on labor supply. Nevertheless, Figure 2 shows a distinct rise in the labor force participation of DI participants as they attain their full retirement age. In the period prior to FRA (at ages 63-64), 4.5 percent are working, whereas in the period after FRA (at ages 65-66) 6.1 percent are working. The rise in labor force participation persists (and perhaps even rises a bit further) until at least ages 69-70. This pattern is particularly dramatic in light of the declining trend in labor force participation with age in the non-DI population. Figure 4 illustrates this stark difference, showing the labor force participation rate for DI recipients on the left axis, and that for non-DI recipients on the right axis. Among non-DI recipients, the percent working for pay falls from 45.0 percent at 63-64 to 35.7 percent at 65-66. Table 2 shows that the DD estimate implied by Figure 4 is 0.109 . The estimate is identical whether based on differenced group means or means of within-individual differences. Also notable is the precipitously declining pre-period trend in labor force participation among those receiving DI at 63-64. Most were already receiving DI prior to ages 63-64, but some were not 
and the drop in labor force participation reflects the gradual movement of this group out of the labor force and onto DI (note that in Figure 2 the DI participation rate rises substantially between ages 59 and 64). In sum, pre-period trends in labor force participation in both the treatment group and comparison group were declining, making the rise in labor force participation by DI participants at full retirement age all the more notable.

Figure 4 shows the age profiles in labor force participation for the two groups split according to whether full retirement age was attained before or after 2002. Most of the policy changes described in Section 2 took effect after our sample was interviewed in 2000; therefore 2002 is the first HRS survey year in which we could potentially detect differences associated with these policy changes. ${ }^{15}$ Within both groups, labor force participation rates between ages 59-62 are the same, but by ages 63-64 labor force participation is higher among the subgroups attaining their FRA after 2002. The decline in labor force participation at FRA for non-DI participants is similar before and after 2002, but the rise in labor force participation at FRA for DI participants appears to be greater. This pattern is consistent with a dose-response relationship between the size of the reduction in the work disincentive and the size of the rise in labor supply—prior to 2000 the DI work disincentives were partially eliminated at FRA, whereas after 2000, the DI work disincentives were completely eliminated at FRA. ${ }^{16}$

Another intriguing aspect of Figure 4 is the greater labor force participation of DI participants in the period prior to FRA; this raises the possibility that the policy changes aimed at improving work incentives during this period (including the initiation of the Ticket to Work

\footnotetext{
${ }^{15}$ Nearly half (48\%) of the HRS cohort had their Wave 5 interview before or during April 2000, when the Senior Citizens' Freedom to Work Act was signed into law.

${ }^{16}$ Although we interpret the relative rise in LFP after 2002 as being a result of the removal of the Social Security earnings test, it may also reflect the effect of the TWWIIA if those who participated in the Ticket to Work program while on DI later benefited from the access to employment services and networks. Given the low early participation rate in Ticket to Work program any such effect is likely to be small.
} 
program) may have had detectable effects. Of course, labor force participation in the period prior to FRA is also higher among non-DI participants, so careful analysis of alternative explanations (such as birth cohort effects) is necessary before any conclusions may be drawn about the effects of these policies on individuals while enrolled in DI.

\subsection{Models}

Let $\Delta Y_{i j t}$ denote the change in labor supply outcome $Y$ for individual $i=1, \ldots, N$ in treatment group $j=1,2$ between time $t$ and $t-2 ; \Delta X_{i j t}$ is the change in individual characteristics between time $t$ and $t-2 ; D_{j}$ is an indicator for being in the treatment group; and $\varepsilon_{i j t}$ is an individual-specific error term. We begin with a two-period model in which $t-2$ denotes the preperiod and $t$ the post-period, and we estimate a linear equation of the following form:

$$
\Delta Y_{i j t}=\alpha+D_{j} \beta+\Delta X_{i j t} \pi+\varepsilon_{i j t}
$$

In this two-period pre/post model, the coefficient $\beta$ is the DD estimate of the effect of relaxing the DI work disincentive and $\alpha$ captures a linear time trend in $Y_{i j t}$. We also expand the specification beyond the simple two-period pre-/post- comparison to allow multiple pre- and post-periods. In Figure 4, we saw that the shape of the age profile is different for the treatment and comparison groups; thus we interact a flexible function of $t$ with the treatment group indicator $D_{j}$ in order to allow the slopes of the age profile to differ before and after full retirement age and across groups.

$$
\Delta Y_{i j t}=D_{j} \beta+\left(D_{j}^{*} f(t)\right) \delta+f(t) \phi+\Delta X_{i j t} \pi+\varepsilon_{i j t}
$$

We model $f(t)$ as a sequence of dummy variables for each period $t$. If we set the reference period to be the first post-period, then the coefficient $\beta$ continues to be the DD estimate.

\subsection{Potential Confounders}


An attraction of the first-differenced model shown in (1) and (2) is that permanent unobservable differences between DI beneficiaries and non-beneficiaries are differenced out. This is desirable in light of the many differences between the two groups shown in Table 1. However, the existence of pre-period differences also suggests that time-varying processes may differentially impact the two groups (Meyer, 1995). In particular, health shocks might differentially impact the DI group given their lower initial health status. Another domain of vulnerability are changes associated with attaining full retirement age. For example, given that most DI beneficiaries already qualify for Medicare, we would expect only a modest rise in health insurance coverage among this group as those who entered DI at or after age 63 qualify for Medicare at 65. On the other hand, we expect a larger rise in health insurance coverage for the non-DI group as the uninsured gain health insurance coverage through Medicare at age 65 . Similarly, although DI benefits are converted to SSA retirement benefits at full retirement age, the benefit amount itself does not change. On the other hand, many non-DI beneficiaries claim OASI retirement benefits at full retirement age, although the majority (on average 68\% between 1992 to 2006) ${ }^{17}$ claim OASI benefits before FRA.

One way of testing for the presence of confounders is to estimate models like those in equations (1) or (2) for each potential confounder. ${ }^{18}$ Table 3 shows DD estimates based on equation (1) for 22 potential confounders, including household size, financial variables, health insurance coverage, and many measures of health status. The estimation sample has one firstdifferenced observation per respondent. Statistically significant estimates are evidence that the treatment group experienced differential pre-/post-FRA changes in a given variable. There is little evidence of differential impacts for pre-/post-FRA changes in household size, net worth,

\footnotetext{
${ }^{17}$ Authors' calculation according to the Social Security Annual Statistical Supplement 2007 Table 6.B5.

${ }^{18}$ This is similar in spirit the test offered by Lee (2008) in the context of regression discontinuity designs.
} 
capital income, private pension income, income received from SSA (including DI and OA retirement income), other government transfer income, and other income (this latter category includes, for example, lump sum amounts received from private pensions). On the other hand the coefficient in column (8) indicates that the control group experienced a large differential change in health insurance coverage at FRA. As noted earlier, this captures enrollment of uninsured non-DI beneficiaries in Medicare at age 65, which for birth cohorts in our sample occurs either exactly at or within the six months prior to attaining full retirement age. There are also differential changes in several measures of health status, though the effects often run in opposite directions. For example, column (9) indicates that the control group experienced a greater increase in the probability of reporting fair or poor health and greater onset of arthritis, but the treatment group saw greater increases in the numbers of activity limitations (ADLs and IADLs) and the total number of health conditions reported, specifically diabetes, heart disease, stroke, and mental health problems. On balance, these results suggest that the treatment group became relatively less healthy at FRA, which would tend to work against detection of a labor supply response at FRA; on the other hand, the large relative rise in health insurance coverage for the control group might inflate the labor supply response of DI participants as the control group reduces labor supply in response to the gain in insurance coverage.

To control for these important time-varying processes, we follow two approaches. The first is to simply include these variables in first-differences in the vector $\Delta X_{i j t}$ in equations (1) and (2). However, this specification assumes that these factors had the same effect on the treatment group as the comparison group, and the evidence in Table 3 raises the possibility of differential effects. Our second approach involves fully interacting the first-differenced confounding variables with the treatment dummy as follows: 


$$
\Delta Y_{i j t}=D_{j} \beta+\left(D_{j}^{*} f(t)\right) \delta+f(t) \phi+\left(D_{j}^{*} \Delta X_{i j t}\right) \varphi+\Delta X_{i j t} \pi+\varepsilon_{i j t}
$$

This fully interacted model is equivalent to running separate models for the treatment and control groups, each with the full set of control variables, and differencing the estimated within-group effects of attaining the FRA on labor supply to obtain $\beta$.

\subsection{Results}

Table 4 presents several OLS specifications of equation (1), which contrasts pre-/postFRA changes in labor supply for the treatment and comparison groups. The estimation sample has one first-differenced observation per respondent. Our main focus is the extensive labor supply margin—working for pay; however, we will also present models for several intensive margin outcomes, including earnings, hours worked per week and weeks worked per year. To illustrate the impact of controlling for the potential confounders shown in Table 3, we enter the $\Delta X_{i j t}$ variables sequentially in groups. Column (1) shows the unadjusted DD estimate of $\beta$ from Table 2 for reference (0.109). In column (2) we add first-differenced demographic variables (household size and an indicator for being married) and financial variables (net worth, capital income, private pension income, SSA income, other government transfer income, and other income). The DD estimate of $\beta$ declines slightly, to 0.100. Among the control variables, only the married indicator, net worth, and SSA income are themselves statistically significant (not shown), indicating that positive changes in net worth and SSA income as well as entering marriage are associated with reductions in labor supply. In column (3) we add the extensive set of first-differenced health controls listed in Tables 1 and 3. Again, the DD estimate of $\beta$ hardly changes; only the fair/poor health indicator is statistically significant (not shown), indicating that entering fair/poor health is associated with a reduction in labor supply. Column (4) adds changes in health insurance coverage. In this case, the DD estimate of $\beta$ reverts back to $0.109(0.013)$. 
In column (5) we interact all covariates with the treatment dummy and the estimate of $\beta$ falls slightly to 0.090 . Finally, in column (6) we use multiple pre- and post- periods as well as fully interacted covariates, as shown in equation (3), and the estimate of $\beta$ rises to $0.104((0.012)$. In all of these first-differenced specifications, we calculate the standard errors allowing for arbitrary correlation in the labor supply within the treatment and control groups in a given year. For the two-period models shown in columns (1)-(5) we use calendar years and obtain 22 groupcalendar year clusters. In the multi-period model shown in column (6) we cluster by treatment group and time period relative to FRA, which gives 6 periods*2 groups=12 clusters.

In Table 5, we examine whether the estimated treatment effect differs for individuals who attained FRA before and after 2002. The DD estimate of $\beta$ (based on equation (3)) is 0.089 before 2002 and 0.128 in 2002 or later. Although the two coefficients are not statistically different $(t=-1.3)$, the substantial rise after 2002 is suggestive of a dose-response relationship between labor force participation and the magnitude of work disincentives. For comparison, Song and Manchester (2007) found that work participation among OASI beneficiaries ages 6569 increased by one to two percentage points after the removal of earnings test. Our implied point estimate for DI beneficiaries is higher (3.9 percentage points), but not statistically different from zero.

Finally, we test for labor supply effects in other related outcomes, notably hours worked per week, the percent working full-time, weeks worked per year, the percent working full-year, earnings, and the percent with earned income above the SGA threshold. Estimating equation (3) for each outcome, Table 6 shows consistent evidence of a treatment effect across outcomes. 
Hours per week rose by 4.3 hours ${ }^{19}$ (compared to an unconditional mean of 1.1 hours per week among DI participants in the period before FRA); the percent working full-time rose by 8.0 percentage points (on a base of 1.6 percent); weeks per year rose by 5.1 weeks (on a base of 1.6 weeks); the percent working full-year (>=50 weeks per year) rose by 8.8 percentage points (on a base of 2.4 percent); annual earnings rose by $\$ 3,006$ (on a base of $\$ 755$ ), and the percent with earnings above the SGA threshold rose by 7.2 percentage points (on a base of 2.5 percent). Comparing this last figure to our estimated 10.4 percent increase in the percent working indicates that about 70 percent of the rise in labor force participation at full retirement age was to earnings levels above SSA's threshold for substantial gainful activity.

Finally, we also tested whether the labor supply response varies across individuals with different kinds of health conditions. We found suggestive evidence that the labor supply response was greater among those who were relatively healthier (for example, those with no activity limitations compared to those one or more), but a positive labor supply effect persisted even in subsamples of relatively less healthy individuals. This suggests that initiatives to improve the DI work incentives need not be targeted at only the healthiest respondents.

\section{Conclusion}

Our results suggest that even the oldest DI recipients respond to changes in work incentives, and underscore the existence of untapped work capacity among even the oldest DI beneficiaries. The effects we document are large increases in percent terms; however, they do not suggest that all or even most DI beneficiaries can or would work. Our adjusted differencein-difference (DD) estimates imply a 10.4 percentage point rise in labor force participation at full retirement age among former DI participants relative to non-DI participants. There is weak

\footnotetext{
${ }^{19}$ Our estimate of the change in hours corresponds to roughly 25 hours per month, which is somewhat lower than Chen and van der Klaauw’s (2008) estimate of 30 hours per month.
} 
evidence that the labor supply response was stronger after elimination of the Social Security earnings test, which suggests the existence of a dose-response relationship between the size of the work disincentive and labor supply. We also document corresponding increases in related measures of labor supply including hours worked per week, weeks worked per year, annual earnings, and the percent earning above SSA's threshold for substantial gainful activity. Given that we have identified a labor supply response among those DI beneficiaries arguably least likely to work, we present our estimates as a lower bound on the work capacity of DI beneficiaries. Combining our estimates with recent work establishing an upper bound on the work capacity of DI beneficiaries (Chen and van der Klaauw 2008) suggests that the DI program causes a modest 10-20 percentage point reduction in labor force participation. 


\section{References}

Autor, David H and Duggan, Mark G. "The Rise in the Disability Rolls and the Decline in Unemployment." Quarterly Journal of Economics, 2003, 118(1), pp. 157-205.

Benítez-Silva, Hugo, Buchinsky, Moshe, and Rust, John. "Induced Entry Effects of a \$1 for \$2 Offset in SSDI Benefits.” 2006. Manuscript.

Bound, John. "The Health and Earnings of Rejected Disability Insurance Applicants." American Economic Review, 1989, 79(3), pp. 482-503.

Bound, John and Waidmann, Timothy. "Accounting for Recent Declines in Employment Rates among Working-Aged Men and Women with Disabilities." Journal of Human Resources, 2002, 37(2), pp. 231-50.

Bound, John and Waidmann, Timothy. "Disability Transfers, Self-Reported Health, and the Labor Force Attachment of Older Men: Evidence from the Historical Record." Quarterly Journal of Economics, 1992, 107(4), pp. 1393-419.

Chen, Susan and van der Klaauw, Wilbert. "The Work Disincentive Effects of the Disability Insurance Program in the 1990s," Journal of Econometrics, 2008, 142(2), pp. 757-784.

Coe, Norma, Gregory Acs, Robert I. Lerman, Keith Watson. "Does Work Pay? A Summary of the Work Incentives under TANF.” Washington D.C.: Urban Institute, No. A-28. 1998.

Gruber, Jonathan. "Disability Insurance Benefits and Labor Supply." Journal of Political Economy, 2000, 108(6), pp. 1162-83.

Gruber, Jonathan and Kubik, Jeffrey D. "Disability Insurance Rejection Rates and the Labor Supply of Older Workers." Journal of Public Economics, 1997, 64(1), pp. 1-23.

Halpern, Janice and Hausman, Jerry. "Choice Under Uncertainty: A Model of Applications for the SSDI Program.” Journal of Public Economics, 1986, 31(2), pp. 131-61.

Lee, David. "Randomized Experiments from Non-random Selection in U.S. House Elections." Journal of Econometrics, 142(2) 675-697.

Maestas, Nicole and Li, Xiaoyan. "Discouraged Workers? Job Search Outcomes of Older Workers," MRRC Working Paper \#2006-133. 2006.

Mathematica. "Evaluation of the Ticket to Work Program - Assessment of Post-Rollout Implementation and Early Impacts.” 2007.

Meyer, Bruce D. "Natural and Quasi-Experiments in Economics.” Journal of Business \& Economic Statistics, 1995, 13(2), pp. 151-161. 
Social Security Administration. "Trends in the Social Security and Supplemental Security Income Disability Programs." SSA Publication No. 13-11831, 2006.

Social Security Administration. "Annual Statistical Report on the Social Security Disability Insurance Program, 2007.” SSA Publication No. 13-11826, 2008.

Song, Jae G. and Manchester, Joyce. "New Evidence on Earnings and Benefit Claims Following Changes in the Retirement Earnings Test in 2000.” Journal of Public Economics, 2007, 91, pp. 669-700.

Yin, Na. "Partial Disability Benefits in the Social Security Disability Insurance Program: A Policy Alternative to Foster Work among the Disabled.” mimeo, 2008. 
Figure 1. DI Budget Constraint

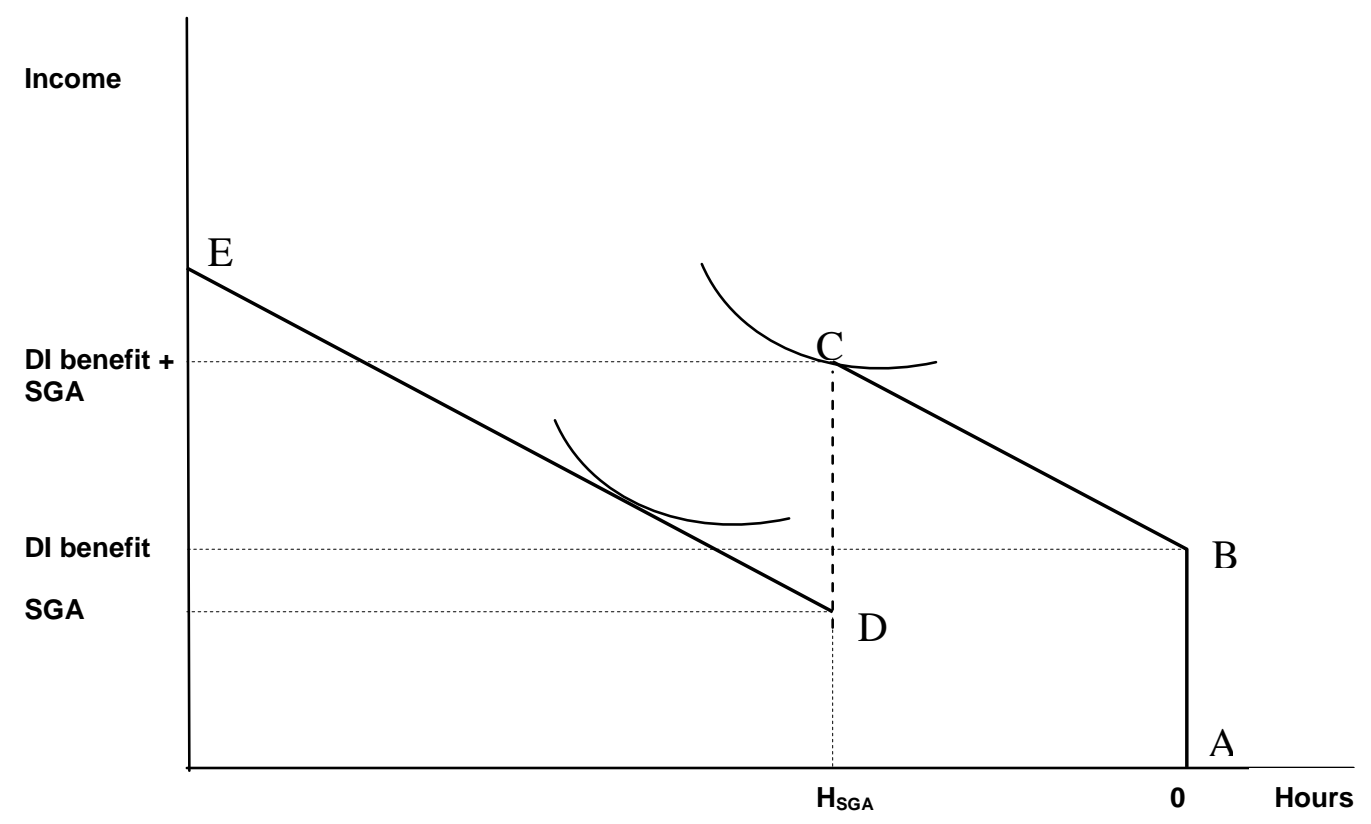


Figure 2. Age Profile in DI Program Participation and Labor Force

Participation

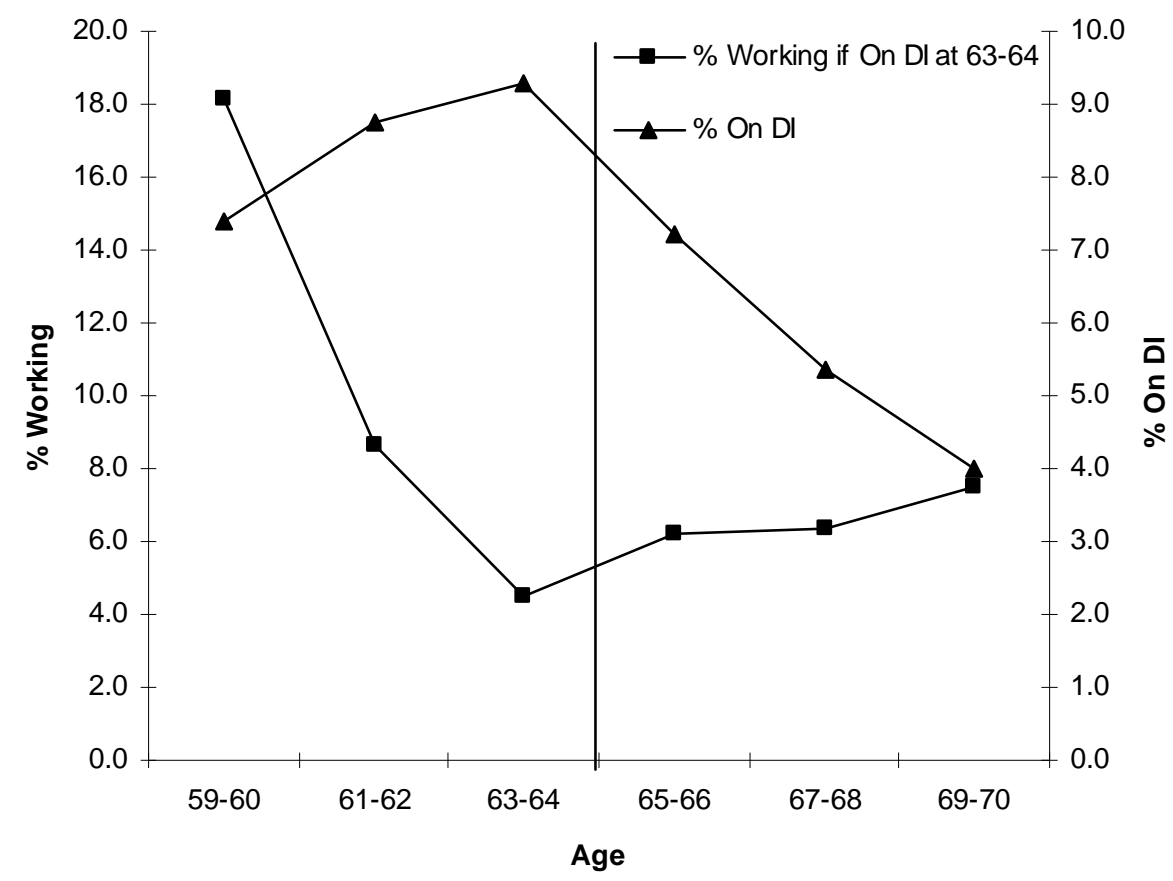

Figure 3. Age Profile in Labor Force Participation

by DI Status at Age 63-64

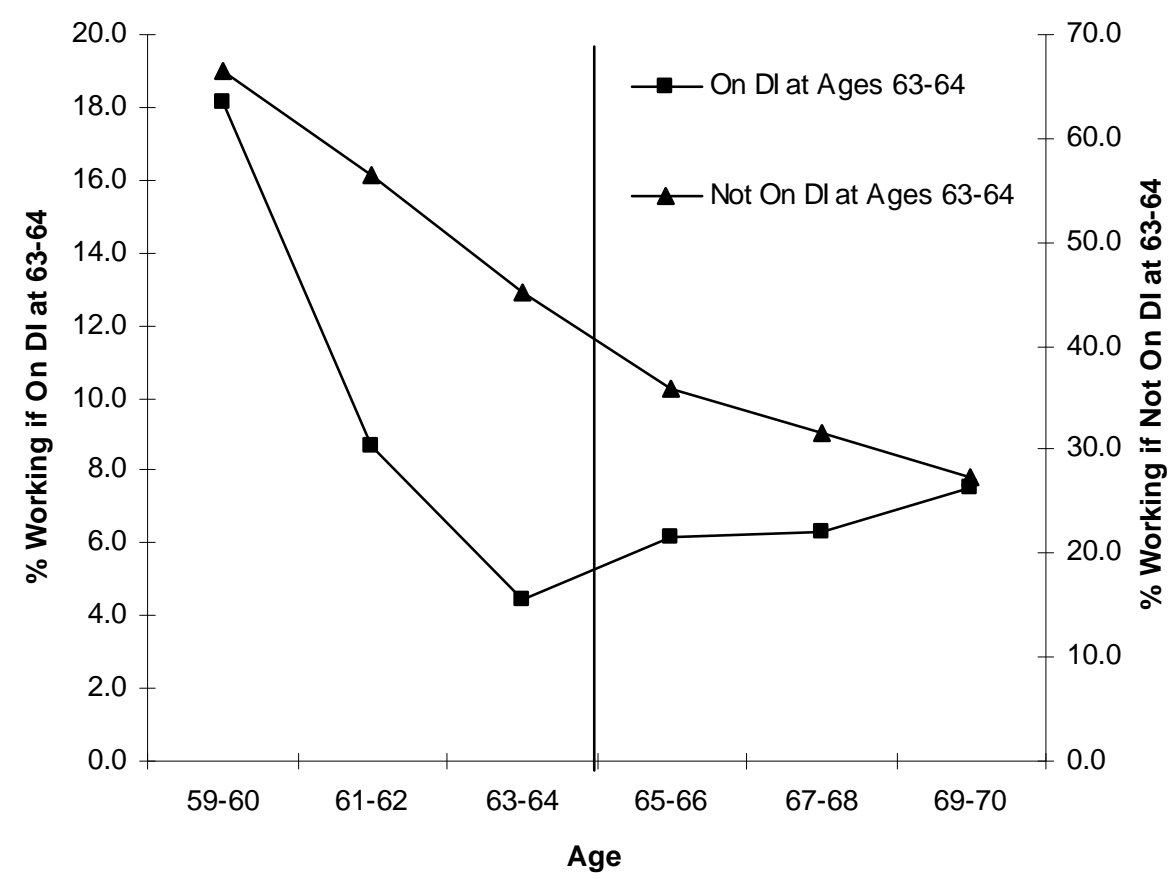


Figure 4. Age Profile in Labor Force Participation

by DI Status at Ages 63-64 and Whether Reached FRA Before/After 2002

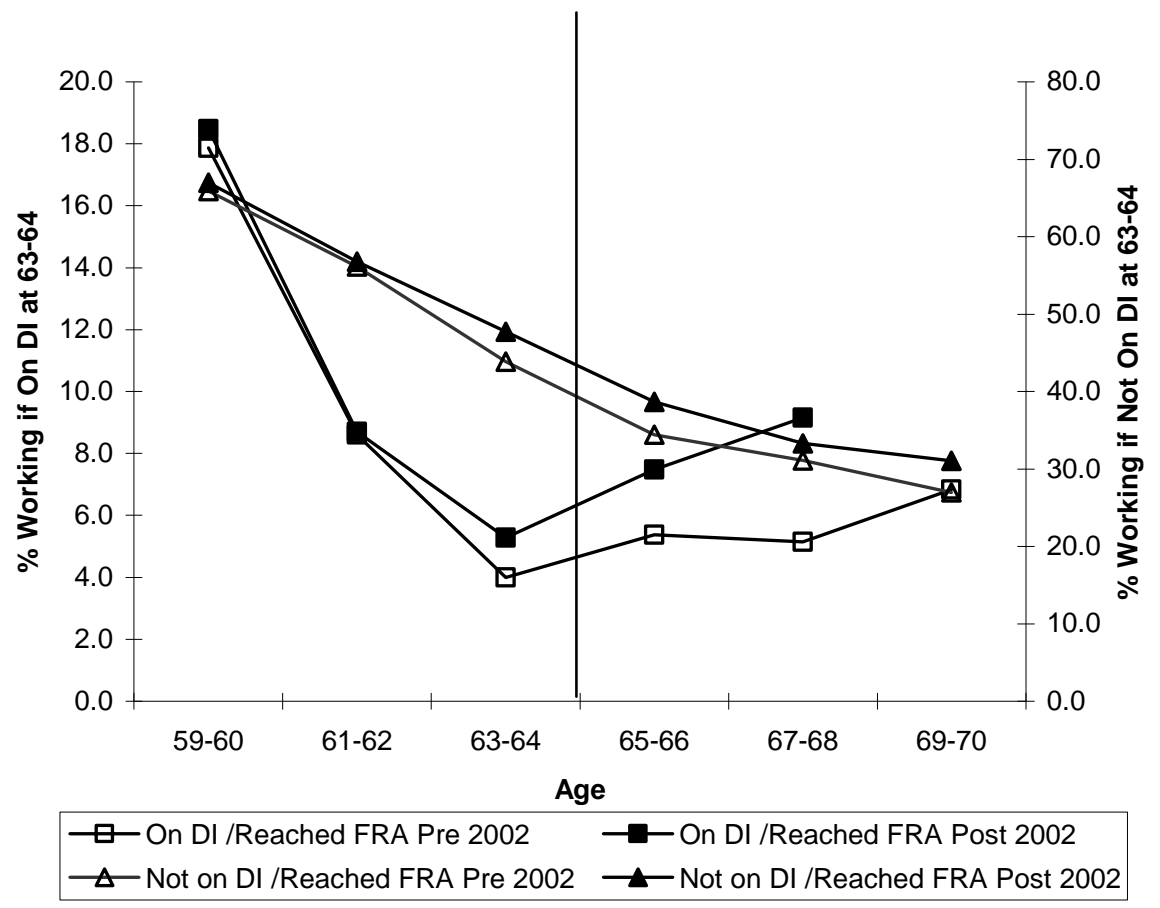


Table 1. Sample Means as of Wave Prior to Full Retirement Age by DI Status

On DI at 63-64 Not on DI at 63-64

Current Age

63.5

63.6

SSA Full Retirement Age (Median)

65.0

65.0

Female

0.47

0.52

Black

0.25

0.14

Hispanic

0.10

0.09

Other

0.03

0.02

Years of Schooling

10.4

12.3

Household Size

2.4

2.3

Married

0.65

0.76

Earnings (\$)

755

16,087

Net Worth (\$)

Capital Income (\$)

185,220

3,903

444,856

Private Pension Income (\$)

2,638

17,455

SSA Income (Incl. DI, SSI, and Retirement Income) (\$)

8,825

5,315

Other Government Transfer Income (\$)

628

5,762

Other Income (\$)

1,066

734

Any Health Insurance Coverage

0.92

2,885

Fair or Poor Self-Reported Health (0-1)

0.73

0.70

Number of ADL Limitations

0.8

0.21

Number of IADL Limitations

0.2

0.2

Ever Had High Blood Pressure

0.62

0.1

Ever Had Diabetes

0.27

0.45

Ever Had Cancer

0.12

0.14

Ever Had Lung Disease

0.22

0.09

Ever Had Heart Disease

0.38

0.07

Ever Had Stroke

Ever Had Psychiatric Problems

0.15

0.16

0.29

0.04

Ever Had Arthritis

0.73

0.09

Number of Major Health Conditions

2.8

0.51

Body Mass Index (BMI)

28.8

1.6

27.6

$\mathrm{N}$

670

6571

Notes: Net worth is the sum of assets (primary residence, other real estate, vehicles, businesses, IRAs, stocks, bonds, checking accounts, CDs, and other assets) less liabilities (mortgages, other home loans, and other debt). ADL refers to Activities of Daily Living and IADL to Instrumental Activities of Daily Living. Major Health Conditions include 1) high blood pressure or hypertension; 2) diabetes or high blood sugar; 3) cancer or a malignant tumor of any kind except skin cancer; 4) chronic lung disease except asthma such as chronic bronchitis or emphysema; 5) heart attack, coronary heart disease, angina, congestive heart failure, or other heart problems; 6) stroke or transient ischemic attack (TIA); 7) emotional, nervous, or psychiatric problems; and 8)arthritis or rheumatism. All dollar amounts in $\$ 2006$. 
Table 2. Employment Rate Before and After FRA for DI Beneficiaries versus Non-Beneficiaries

\begin{tabular}{|c|c|c|c|c|}
\hline & $\begin{array}{c}\text { Wave } \\
\text { Before FRA } \\
(1) \\
\end{array}$ & $\begin{array}{c}\text { Wave } \\
\text { After FRA } \\
(2) \\
\end{array}$ & $\begin{array}{c}\text { Across Group } \\
\text { Change } \\
(3)\end{array}$ & $\begin{array}{c}\text { Within-Individual } \\
\text { Change } \\
(4)\end{array}$ \\
\hline On DI & 0.045 & 0.061 & $\begin{array}{r}0.016 \\
(0.015)\end{array}$ & $\begin{array}{r}0.016 \\
(0.011)\end{array}$ \\
\hline Not on DI & 0.450 & 0.357 & $\begin{array}{r}-0.093 \\
(0.006)\end{array}$ & $\begin{array}{r}-0.093 \\
(0.005)\end{array}$ \\
\hline \multicolumn{3}{|c|}{ DD Estimate of Treatment Effect } & $\begin{array}{r}0.109 \\
(0.016)\end{array}$ & $\begin{array}{r}0.109 \\
(0.012)\end{array}$ \\
\hline
\end{tabular}

Note: Standard errors clustered by treatment group and calendar year. DI participation is measured as of the Wave before FRA (ages 63-64). Col 3 is Col 2 minus Col 1. Col 4 is mean within-individual after-minus-before change in employment rate. 
Table 3. Tests for Differential Pre-/Post Changes in Potential Confounders for Treatment versus Comparison Groups

\begin{tabular}{|c|c|c|c|c|c|c|c|c|c|c|c|}
\hline & $\begin{array}{l}\Delta \text { Household } \\
\text { Size } \\
(1)\end{array}$ & $\begin{array}{l}\Delta \text { Net } \\
\text { Worth } \\
(2)\end{array}$ & $\begin{array}{l}\Delta \text { Capital } \\
\text { Income } \\
(3)\end{array}$ & $\begin{array}{l}\Delta \text { Pension } \\
\text { Income } \\
(4)\end{array}$ & $\begin{array}{l}\triangle S S A \\
\text { Income } \\
(5)\end{array}$ & $\begin{array}{l}\Delta \text { Oth Gov } \\
\text { Xfer Inc } \\
\text { (6) }\end{array}$ & $\begin{array}{l}\Delta \text { Other } \\
\text { Income } \\
(7)\end{array}$ & $\begin{array}{l}\triangle \text { Any } \\
\text { Health Ins } \\
\text { (8) }\end{array}$ & $\begin{array}{l}\Delta \text { Fair/Poor } \\
\text { Health } \\
(9)\end{array}$ & $\begin{array}{l}\Delta \text { Total } \\
\text { ADLs } \\
(10)\end{array}$ & $\begin{array}{l}\Delta \text { Total } \\
\text { IADLs } \\
(11)\end{array}$ \\
\hline $\begin{array}{l}D_{j} \\
\text { No. Obs }\end{array}$ & $\begin{array}{l}0.033 \\
(0.030) \\
7241\end{array}$ & $\begin{array}{l}-55.26 \\
(34.007) \\
7241\end{array}$ & $\begin{array}{l}0.729 \\
(1.076) \\
7241\end{array}$ & $\begin{array}{l}-0.693 \\
(0.359) \\
7241\end{array}$ & $\begin{array}{l}-0.038 \\
(0.483) \\
7241\end{array}$ & $\begin{array}{l}0.023 \\
(0.076) \\
7241\end{array}$ & $\begin{array}{l}-0.453 \\
(0.580) \\
7241\end{array}$ & $\begin{array}{l}-0.203^{* *} \\
(0.019) \\
7241\end{array}$ & $\begin{array}{l}-0.041 \\
(0.038) \\
7241\end{array}$ & $\begin{array}{l}0.121^{*} \\
(0.057) \\
7234\end{array}$ & $\begin{array}{l}0.087^{* *} \\
(0.027) \\
6930\end{array}$ \\
\hline & $\begin{array}{l}\triangle \text { CESD } \\
\text { Scale } \\
(12)\end{array}$ & $\begin{array}{l}\text { Onset } \\
\text { HBP } \\
(13)\end{array}$ & $\begin{array}{l}\text { Onset } \\
\text { Diabetes } \\
(14)\end{array}$ & $\begin{array}{l}\text { Onset } \\
\text { Cancer } \\
(15)\end{array}$ & $\begin{array}{l}\text { Onset } \\
\text { Lung Dis } \\
(16)\end{array}$ & $\begin{array}{l}\text { Onset } \\
\text { Heart Dis } \\
(17)\end{array}$ & $\begin{array}{l}\text { Onset } \\
\text { Stroke } \\
(18)\end{array}$ & $\begin{array}{l}\text { Onset } \\
\text { Psych } \\
(19)\end{array}$ & $\begin{array}{l}\text { Onset } \\
\text { Arthritis } \\
(20)\end{array}$ & $\begin{array}{l}\Delta \text { Total } \\
\text { Conditions } \\
(21)\end{array}$ & $\begin{array}{l}\triangle \mathrm{BMI} \\
(22)\end{array}$ \\
\hline $\begin{array}{l}D_{j} \\
\text { No. Obs }\end{array}$ & $\begin{array}{l}-0.102 \\
(0.103) \\
6282\end{array}$ & $\begin{array}{l}-0.005 \\
(0.009) \\
7234\end{array}$ & $\begin{array}{l}0.020 * * \\
(0.007) \\
7225\end{array}$ & $\begin{array}{l}0.005 \\
(0.008) \\
7217\end{array}$ & $\begin{array}{l}0.003 \\
(0.006) \\
7230\end{array}$ & $\begin{array}{l}0.018 \\
(0.010) \\
7229\end{array}$ & $\begin{array}{l}0.023^{*} \\
(0.011) \\
7234\end{array}$ & $\begin{array}{l}0.011 \\
(0.008) \\
7227\end{array}$ & $\begin{array}{l}-0.024^{* *} \\
(0.006) \\
7225\end{array}$ & $\begin{array}{l}0.050 * \\
(0.023) \\
7241\end{array}$ & $\begin{array}{l}-0.132 \\
(0.107) \\
7110\end{array}$ \\
\hline
\end{tabular}

Notes: Columns are separate regressions based on Equation (1) for first-differenced dependent variable listed in column head, where differences are taken between the wave just after FRA and the wave just before FRA. $D_{j}$ is a dummy for being on DI in the wave just before FRA (at ages 63-64), and thus its

coefficient measures the relative change in the dependent variable for the group on DI relative to individuals not on DI. Data are from the Health and Retirement Study, 1992-2006. Loss in sample size for IADL and CESD variables is from dropping Wave 1 responses because of incomparable survey questions. Standard errors, in parentheses, are clustered by treatment group and calendar year. *denotes $5 \%$ significance and ** indicates $1 \%$ significance. HBP stands for High Blood Pressure. 


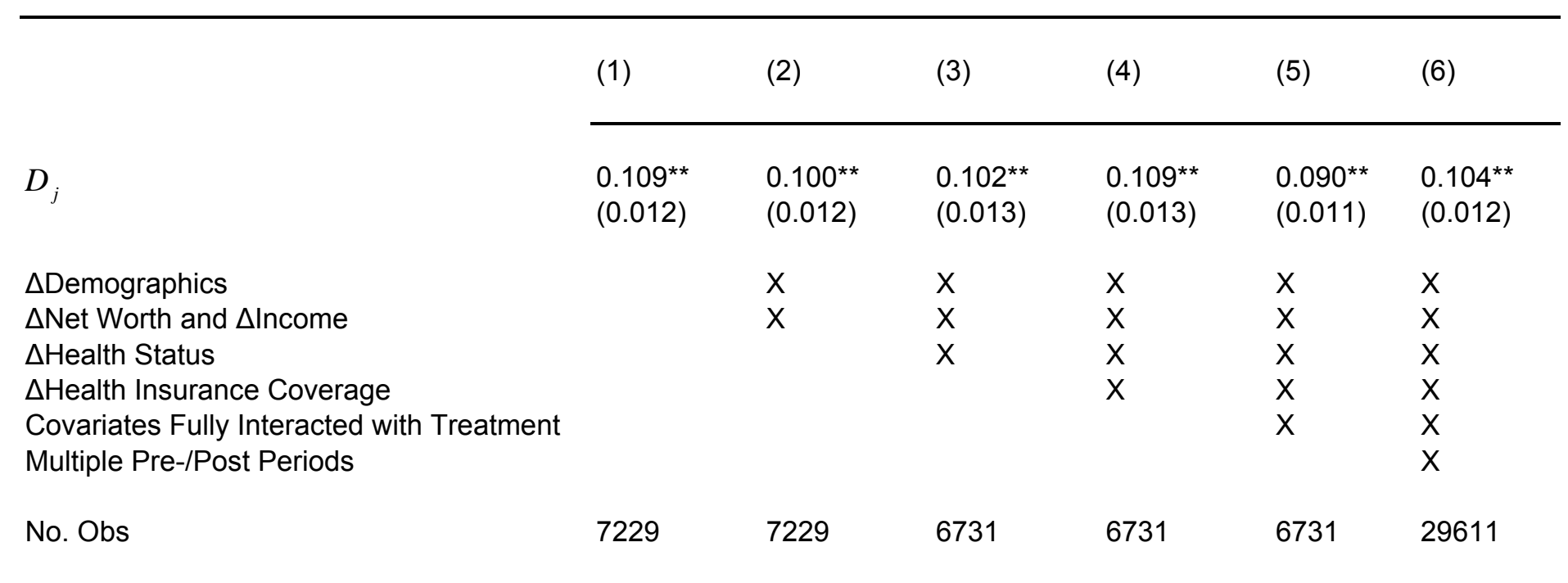

Notes: Columns (1)-(5) are separate regressions based on Equation (1) for first-differenced working for pay, where differences are taken between the wave just after FRA and the wave just before FRA. Column (6) is based on Equation (2) for first-differenced working for pay, where wave-to-wave differences are taken across three waves prior to FRA and three waves afer FRA. $D_{j}$ is a dummy for being on DI in the wave just before FRA (at ages 63-64). Data are from the Health and Retirement Study, 1992-2006. Demographic variables include household size and an indicator if married. Income variables include capital income, private pension income, SSA income, other government transfer income, and other income. Health Status variables include all health variable listed in Table 1. Loss in sample size in columns (3), (4), and (5) is from dropping Wave 1 responses because of incomparable survey questions on IADL items. Standard errors ( in parentheses) for two-period models shown columns (1)-(5) are clustered by treatment group and calendar year (22 clusters), while standard errors for multi-period model in column (6) are clustered by treatment group and time period relative to FRA (12 clusters). ${ }^{*}$ denotes $5 \%$ significance and ${ }^{* *}$ indicates $1 \%$ significance. 
Table 5. Adjusted DD Estimates of Effect of Relaxing DI Work Disincentive on Employment Rate, Before and After 2002

\begin{tabular}{|c|c|c|}
\hline & $\begin{array}{l}\text { Turn FRA } \\
\text { Before } 2002 \\
\text { (1) }\end{array}$ & $\begin{array}{l}\text { Turn FRA } \\
\text { In or After } 2002 \\
(2)\end{array}$ \\
\hline$D_{j}$ & $\begin{array}{l}0.089^{* *} \\
(0.014)\end{array}$ & $\begin{array}{l}0.128^{\star *} \\
(0.029)\end{array}$ \\
\hline$\Delta$ Demographics & $x$ & $x$ \\
\hline$\Delta$ Net Worth and $\Delta$ Income & $X$ & $x$ \\
\hline$\Delta$ Health Status & $X$ & $\mathrm{X}$ \\
\hline$\Delta$ Health Insurance Coverage & $\mathrm{X}$ & $\mathrm{X}$ \\
\hline Covariates Fully Interacted with Treatment & $X$ & $\mathrm{X}$ \\
\hline Multiple Pre-/Post Periods & $x$ & $x$ \\
\hline No. Obs & 18305 & 11306 \\
\hline
\end{tabular}

Notes: Columns are separate regressions based on Equation (2) for first-differenced working for pay, where wave-to-wave differences are taken across three waves prior to FRA and three waves after FRA, and where all (first-differenced) covariates are fully interacted with the treatment dummy, $D_{j}$ (being on $\mathrm{DI}$ in the wave just before FRA). Data are from the Health and Retirement Study, 1992-2006. Demographic variables include household size and an indicator if married. Income variables include capital income, private pension income, SSA income, other government transfer income, and other income. Health Status variables include health variables listed in Table 1. Standard errors, in parentheses, are clustered by treatment group and time period relative to FRA ( 6 periods 2 groups $=12$ clusters). *denotes $5 \%$ significance and ${ }^{* *}$ indicates $1 \%$ significance. 
Table 6. Adjusted DD Estimates of Effect of Relaxing DI Work Disincentive on Hours, Weeks, and Earnings

\begin{tabular}{|c|c|c|c|c|c|c|}
\hline & $\begin{array}{l}\Delta \text { Hours per } \\
\text { Week } \\
\text { (1) }\end{array}$ & $\begin{array}{l}\Delta \text { Weeks per } \\
\text { Year } \\
(2)\end{array}$ & $\begin{array}{l}\Delta \text { Works } \\
\text { Full-Time } \\
(3)\end{array}$ & $\begin{array}{l}\Delta \text { Works } \\
\text { Full-Year } \\
(4)\end{array}$ & $\begin{array}{l}\Delta \text { Annual } \\
\text { Earnings } \\
(5)\end{array}$ & $\begin{array}{l}\Delta(\text { Earnings }>= \\
\mathrm{SGA}) \\
(6)\end{array}$ \\
\hline$D_{j}$ & $\begin{array}{l}4.288^{* *} \\
(0.414)\end{array}$ & $\begin{array}{l}5.093^{* *} \\
(0.479)\end{array}$ & $\begin{array}{l}0.080^{* *} \\
(0.008)\end{array}$ & $\begin{array}{l}0.088^{* *} \\
(0.009)\end{array}$ & $\begin{array}{l}3,005.699^{* *} \\
(416.312)\end{array}$ & $\begin{array}{l}0.072^{* *} \\
(0.009)\end{array}$ \\
\hline$\Delta$ Demographics & $\mathrm{X}$ & $x$ & $\mathrm{X}$ & $X$ & $\mathrm{X}$ & $\mathrm{X}$ \\
\hline$\Delta$ Net Worth and $\Delta$ Income & $\mathrm{X}$ & $x$ & $\mathrm{X}$ & $X$ & $\mathrm{X}$ & $\mathrm{X}$ \\
\hline$\Delta$ Health Status & $\mathrm{X}$ & $x$ & $\mathrm{X}$ & $X$ & $\mathrm{X}$ & $\mathrm{X}$ \\
\hline$\Delta$ Health Insurance Coverage & $\mathrm{X}$ & $\mathrm{X}$ & $\mathrm{X}$ & $\mathrm{X}$ & $\mathrm{X}$ & $\mathrm{X}$ \\
\hline Covariates Fully Interacted with Treatment & $\mathrm{X}$ & $X$ & $\mathrm{X}$ & $\mathrm{X}$ & $\mathrm{X}$ & $\mathrm{X}$ \\
\hline Multiple Pre-/Post Periods & $x$ & $x$ & $x$ & $x$ & $x$ & $x$ \\
\hline Mean for DI Participants at $63-64$ & 1.135 & 1.603 & 0.016 & 0.024 & 754.518 & 0.025 \\
\hline No. Obs & 29083 & 28976 & 29611 & 29611 & 29642 & 29642 \\
\hline
\end{tabular}

Notes: Columns are separate regressions based on Equation (2) for first-differenced variable in column head, where wave-to-wave differences are taken across three waves prior to FRA and three waves after FRA, and where all (first-differenced) covariates are fully interacted with the treatment dummy, $\mathrm{Dj}$ (being on DI in the wave just before FRA). Working Full-Time is hours per week $>=35$ and Working Full-Year is weeks per year $>=50$. Data are from the Health and Retirement Study, 1992-2006. Demographic variables include household size and an indicator if married. Income variables include capital income, private pension income, SSA income, other government transfer income, and other income. Health Status variables include health variables listed in Table 1 . Standard errors, in parentheses, are clustered by treatment group and time period relative to FRA ( 6 periods 2 groups $=12$ clusters). ${ }^{*}$ denotes $5 \%$ significance and ${ }^{* *}$ indicates $1 \%$ significance. 